\title{
La Relación Yo-Tú en la Poesía de Pablo Neruda. Del Autoerotismo al Panerotismo
}

\section{I.-LAS PRISIONES DEL YO}

Crepusculario, El bondero entusiasta, Veinte poemas, Tentativa..., Residencia en la tierra, Cántico general, Los versos del. Capitán... Cien sonetos de amor... Estravagario... Memorial de Isla Negra. . y la larga enumeración de la proteica fecundidad de Pablo Neruda se va haciendo en el lector camino hacia infinita gama de experiencias. Porque Neruda ha querido abarcarlo todo, del apio a la rosa, de la piedra a la estrella, de la sonrisa al aullido, de la soledad a la solidaridad, de Temuco a Macchu Picchu. Y, sin embargo, el camino es uno solo: la lúcida, tenebrosa, contenida, desbocada trayectoria de un yo, el yo de Pablo Neruda.

Desde Crepusculario comienza ese yo, entonces adolescente, a perfilarse y a revelar en indecisos contornos algunos rasgos que perdurarán. Se define entonces, lo mismo que más tarde en Residencia..., como un yo aislado, y en el verso que cierra la primera parte de Crepusculario, hasta voluntariamente incomunicado,

Mi vida es un gran Castillo sin ventanas y sin puertas y para que tú no llegues por esta senda, la tuerzo.

En Tentativa de hombre infinito la imagen recurre, ahora despojada de aderezos finiseculares:

estoy solo en una pieza sin ventanas

sin tener que hacer con los itinerarios extraviados. ${ }^{1}$

1 Pablo Neruda, Obras Completas (Buenos Aires: Editorial Losada, 1967), p. 116. 
No signica esto la completa autosuficiencia del yo, que desde Crepus. culario es un yo deseante del tú femenino, deseado por ser esperanza de evasión onírica o de evasión sexual. Se define el poeta como recep. táculo y senda, $y$ desde entonces es el suyo un yo que recibe:

oh mujer - carne y sueño- ven a encantarme un poco ven a vaciar tus copas de sol en mi camino. ("Ivresse")

Senda y receptáculo es el surco, con el cual se identifica en $E l$ hondero entusiasta,

Te recibo

como el surco a la siembra

Tierra fecunda ha sido siempre la madre, identificada con la amada en su poesía, desde los años adolescentes: ${ }^{2}$

la leche de los senos, como de un manantial. ("Crepusculario")

Mujer, yo hubiera sido tu hijo, por beberte

La total identificación de estos tres elementos, yo, surco de tierra, amada de tierra, madre de tierra, aunque tardará en lograr formulación com. pleta, será la médula misma de la poesía amatoria de su madurez. Así en el quinto de los Cien sonetos de amor, la amada es de tierra, de "greda oscura", en el XXI ella es la madre a quien en sueños busca el niño perdido que Neruda se siente ser, y por fin, en ella el poeta reco. noce, su propia sustancia original,

y toqué en tus caderas los pétalos sombríos

que nacieron conmigo y construyeron mi alma. ("Soneto XXX")

Entre Crepusculario y estos sonetos media casi toda la larga jornada de un yo, en angustiada o jubilosa, clara o confusa búsqueda de su esencia. De ahí las muchas y variadas tentativas de defínición, los distintos tonos de su lírica, los diferentes sujetos y objetos de su poesía. Sin embargo la diferencia es sólo aparente; por los caminos de la palabra, buscando Neruda se busca, recobrando el mundo se recobra, cantando a lo que ama se canta. Porque el poeta, que había sido habitación cerrada, abrió un día la puerta, no tanto para salir por ella, sino para que todo

2 Emir Rodríguez Monegal, El viajero inmóvil (Buenos Aires, 1966), p. 191. 
por ella entrase. Y abarcándolo todo en sí, hecho lo otro - tú o ello-su yo mismo, lo transmutó en cántico a su microcosmos, receptor del del macrocosmos. Esta apetencia cósmica se revela en la constante identificación del cuerpo de la mujer —lo que él puede poseer y abarcarcon la naturaleza:

Cuerpo de mujer, blancas colinas, muslos blancos, te pareces al mundo en tu actitud de entre (Veinte poemas de amor, 1)

Ah nada puedo decir! Era hecha de todas las cosas. (Ibid., 11) Qué pura eres de sol o de noche caída,

qué triunfal desmedida tu órbita de blanco. (Residencia.., I, "Juntos [nosotros")

Pero hasta Las uvas y el viento la amada no es verdaderamente un tú. El poeta está a la orilla de la mujer, y si bien puede haber contacto físico, no hay comunicación, es decir, no hay diálogo. Son estos poemas de amor expresión de su deseo y frustración; la mujer es siempre instrumental, vista o inventada a la medida de sus necesidades:

Para sobrevivirmo te forjé como un arma. (Veinte poemas..., 1) Era la sed y el hambre y tú fuiste la fruta. (Ibid., "Canción desesperada")

Los ojos tienen sed, para qué están tus ojos.

La boca tiene sed, para qué están tus besos. (El bondero..., 11)

De ahí que fuera de la cósmica geografía del cuerpo femenino, nada tiene de realidad concreta este tú, con el cual el poeta monologa en soledad. En muchos de los Veinte poemas ella es la ausente, la lejana, la muda. El poema 15 resume los caracteres esenciales de este tú, amado en y por su silencio, porque su mudez misma es garantía de su leja. nía. El poeta preserva así su melancólica soledad, su castillo cerrado, porque la amada que lo habita es una pura ausencia deseada,

Me gusta cuando callas, porque estás como ausente

Me gusta cuando callas y estás como distante.

Tal como dice en el poema 18, el poeta ama lo que no tiene. Lo que en realidad está amando no es el tú de la ausente, sino su propio ser, 
proyectado en la amada distante; su ser cerrado herméticamente en el círculo de su soledad. Ella - la que no es- es siempre él:

Mi propio latigazo cae sobre mi alma.

Eres lo que está dentro de mí y está lejano,

Huyendo como un coro de nieblas perseguidas.

Junto a mí, pero dónde? Lejos, lo que está lejos

Y lo que estando lejos bajo mis pies camina. (El bondero. ., 10)

La ausencia, el silencio -otro modo de ausencia- son en su adolescencia necesidades absolutas de la modalidad erótica de Neruda, muy evidente en esta época pero curiosamente constante: el narcisismo. Narcisismo que en su madurez llegatá a ser titánico afán de amarse a sí mismo en todo, pero que por ahora se circunscribe a amarse en la amada distante y hasta soñada, en un último esfuerzo de identificación total; poseída sólo como realidad onírica,

¡Cómo te sienten mía mis sueños solitarios! (veinte poemas...., 16)

El poema 15, que en su primera estrofa revela un tú deseado en su silencio y ausencia, en la segunda revela esa calidad de ser sólo sueño y, sobre todo, hace explícita esa invasión del yo del poeta, que subjetiviza toda realidad. La amada es un epifenómeno de esta alma que todo lo incorpora a sí misma:

Como todas las cosas están llenas de mi alma emerges de las cosas llenas del alma mía. Mariposa de ensueño, te pareces a mi alma, y te pareces a la palabra melancolía.

En el poema 8 de $E l$ hondero entusiasta, a esta avidez cósmica del yo une Neruda la función instrumental de la amada, eco suyo, ahora agente necesario para la trascendencia del poeta:

Libértame de mí. Quiero salir de mi alma.

Porque tú eres mi ruta te forjé en lucha viva.

De mi pelea oscura contra mi mismo fuiste.

Tienes de mí ese sello de avidez no saciada. 
Ansiame, agótame, viérteme, sacrifícame.

Haz temblar los cercos de mis últimos límites.

El penúltimo verso citado puede ejemplificar la pasividad erótica de $\mathrm{Ne}$ ruda, reconocida por la crítica en $E l$ bondero entusiasta. Se considera que desde Veinte poemas se inicia una nueva etapa del erotismo del poeta, desde ahora amante activo., La generalización es correcta en cuanto denota una tendencia marcada de su poesía amatoria pero no debe cegarnos a reconocer la pertinaz perduración de la tendencia contraria. En Resi. dencia en la tierra, II, el yo espera aún pasivamente el saludable impulso de la amada:

Tú propagas los besos y matas las hormigas.

Tú lloras de salud, de cebolla, de abeja, de abecedario ardiendo.

Tú eres como una espada, azul y verde $y$ ondulas al tocarte como un río.

Ven a mi alma, vestida de blanco, con un ramo de ensangrentadas rosas y copas de cenizas, ren con una manazana y un caballo, porque allí hay una sala oscura y un candelabro roto.

\section{("Oda con un lamento")}

En "Barcarola" el tú, realidad onírica, postulado de su ansia desesperada, tú entre todos hipotético, es el agente necesario para hacer resonar el corazón del poeta con la voz de su propio llanto. Porque su corazón es un caracol mudo, impotente $\mathrm{y}$ angustiosamente pasivo:

Si existieras de pronto en una costa lúgubre, rodeada por el día muerto y soplaras en mi corazón de miedo frío soplaras en la sangre sola de mi corazón sonarian sus negras sílabas de sangre.

Este tú fantasmal vuelve a ser revestido de atributos cosmicos, pero tam-

\footnotetext{
3 Ibid., pp. 194-195.
} 
poco es esencialmente diferente del yo, pues encierra en sí el llanto del corazón del poeta,

Así es, y los relámpagos cubririan tus trenzas

y la lluvia entraría por tus ojos abiertos

a preparar el llanto que sordamente encierras.

Si el hipotético tú soplase quizá podría poblarse de algún tú real esa pesadilla deshabitada que es la existencia del poeta. Como ya lo había deseado en $E l$ hondero. . a acaso un tú mesiánico podría liberar al yo de su soledad:

Quieres ser el fantasma que sople solitario, cerca del mar su estéril, triste instrumento?

Si solamente llamaras, su prolongado son, su maléfico pito, su orden de olas heridas, alguien vendría acaso, alguien vendría.

Amada ausente, onírica, fantasmal... el tú ha llegado a tener tan poca realidad, que el yo puede solamente ya expresarlo en pura hipótesis. Toda sustancia, objetiva y hasta subjetiva, ha naufragado. Neruda, únicamente atento al clima de su propio estanque, fue un "buzo ciego", ensimismado en su soledad, hasta el punto de no saber quién era verdaderamente el tú al que estaba cantando:

Pensando, enterrando lámparas en la profunda soledad. Quién eres, tú, quién eres? (Veinte poemas..., 17)

El poeta, que había querido ser fluyente tío, se transforma en la "Canción desesperada", en "sentina de escombros, pozo abierto y amargo". Pronto todo será un ir mutiéndose,

Nadie circule! Nadie abra los brazos

dentro del agua ciega! (Residencia..., II, "La calle destruida")

"Rey Midas al revés", como lo llamara Amado Alonso, Neruda que quería abarcar todas las cosas, participa ahora de todas las destrucciones 
y respira "en el aire la ceniza y lo destruido". Así como antes todo era en él, ahora todo en él se deshace, como se le deshace el alma,

Como un naufragio hacia adentro nos morimos, como ahogarnos en el corazón, como irnos cayendo desde la piel al alma (Residencia..., III,

"Sólo la muerte")

Esto ya lo dijo - iy tan bien! - Amado Alonso.

Si Pablo Neruda ve como un incesante morir lo que Heráclito vio como un incesante cambiar de todas las cosas es porque la desintegración de cada ser expresa la contextura emocional del contacto del poeta con el mundo y la vida. El poeta se angustia por el sentido de su vivir. Es la falta de ese necesario sentido lo que hace ver la vida como un naufragio hacia adentro. .. En su naufragio me. tafísico el poeta se agarra de cada cosa, pero cada cosa se hunde con él, porque no le da sentido necesario para su vida. Es esa falta de sentido para sí mismo lo que se traduce en la visión desintegradora. $\mathrm{Su}$ ansia insatisfecha de sentido es el mar de aguas amargas donde se cumple el propio naufragio. Aguas que salen de la intimidad del poeta, $y$ crecen $y$ se desbordan y el mundo se inunda perdiendo su forma, y las cosas son arrastradas en informe bamboleo y mezcla."

El poeta llega en "Walking around" a la sima de todas sus negaciones de valores vitales al negarse a sí mismo, al cansarse de ser hombre. Desde este abismo de negación total deberá Neruda reconstruir su mundo. Claro que para construir hay que hacer, y hasta ahora sólo hemos hablado de la pasividad del poeta que, por cierto, persiste hasta en su erotismo maduro:

Habitaste la casa que te esperaba oscura y encendiste las lámparas entonces. (Los versos del Capitán, "Epitalamio")

Oh invádeme con tu boca abrasadora, indágame si quieres, con tus ojos nocturnos, pero en tu nombre déjame navegar y dormir. (Cien sonetos..., 1)

4 Amado Alonso, Poesia y estilo de Pablo Neruda (Buenos Aires, 1968), pp. 33-34. 
Sin embargo no es ésta la tónica general de su poesía amatoria. Es tiempo ya para nosotros, que hemos presenciado el nadir de su mundo y de su yo, ver la esperanza de reconstrucción en ese mismo erotismo, ahora activo, masculino, acometedor, evidente desde Veinte poemas... En Residencia en la tierra, II, esta sexualidad lejos de ser faro de esperanza, es presentimiento de crimen. La mujer, totalmente pasiva, no es la amada sino una víctima de su agresividad de macho elemental. Hablar de sexualidad activa sería en "Materia nupcial" generalización apresurada. La actividad se da sobre todo, como acontecimiento de orden imaginario. Es ésta una lascivia que se detiene en la contemplación de sí misma. Siendo "Materia nupcial" uno de los poemas más agresivamente sexuales de Neruda, esa agresividad se nos revela, sin embargo, como acontecer interior, preliminar a la acción, cuyo carácter inminente no invalida su calidad de lujuria no actualizada, encerrada en el tiempo futuro y el plano de la imaginación. Lo actual es la contemplación de la víctima y la definición del hombre-macho, a través de la concreta realidad de su cuerpo desnudo. Aunque todo ha naufragado, y la materia y el mundo entero corren en las dos primeras Residencias, irremediablemente hacia el no ser, el yo se recubre, a veces, de cierta materia no exterminada:

Qué pura mi mirada de nocturna influencia, caída de ojos oscuros y feroz acicate, mi simétrica estatua de piernas gemelas sube hacia estrellas húmedas cada mañana.

$Y$ sigue así la contemplativa enumeración de su cuerpo, hasta llegar a "sus pies de riqueza" ("Juntos nosotros"). Jaime Concha y Emir Rodríguez Monegal ${ }^{5}$ ven en los "Tres cantos materiales" una afirmación renovada de la materia; pero Neruda, siendo quien fue y quien es, no podía comenzar a afirmar el mundo desde afuera, desde el ello. Su primer asidero a la realidad, la primera afirmación renovadora de lo positivo $\rightarrow$ para él lo positivo está casi siempre identificado con lo eróticodeberá partir de una afirmación de su propia realidad. $Y$ ha de ser ésta afirmación enamorada. Neruda le canta entonces a sus piernas:

Largamente he permanecido mirando mis largas piernas, con ternura infinita y curiosa, con mi acostumbrada pasión, como si hubieran sido las piernas de una mujer divina.

("Ritual de mis piernas")

5 Jaime Concha, "Interpretación de Residencia en la Tierra", Mapocho, tomo I, número 2 (1963), 5-39, R. Monegal, op. cit., pp, 217-222. 
En sus piernas Neruda reconoce el "compacto material de la existencia"; pero más allá de sus pies, donde termina el yo, siente que co. mienza "lo otro",

todo termina, la vida termina definitivamente a mis pies, lo extranjero y lo hostil allí comienza:

los nombres del mundo, lo fronterizo y lo remoto. ("Ritual de mis piernas")

Todo termina porque siendo lo extranjero, lo ajeno, es lo que Neruda no puede amar; justamente por eso, en "Vals" de la tercera Residencia, puede decir que no conoce a nadie, y quedarse con lo único que siente suyo:

Dejadme en medio de mi propia luna, en $\mathrm{mi}$ territorio herido.

Hasta el tú femenino - que antes fuera amada, amiga o víctimaes ahora lo extraño y lo hostil: la enemiga. Cuando quiere abarcar el mundo Neruda hace que el cuerpo de la amada sea compendio de la Na. turaleza. Ahora que el mundo es sentido como enemigo, hace que la mujer sea condensación de ferocidad cósmica,

porque ahí están tus ojos oliendo a cacería, a rayo verde que agujerea pechos, tus dientes que abren manzanas de las que cae sangre, tus piernas que se adhieren al sol dando gemidos, $\mathrm{y}$ tus tetas de nácar y tus pies de amapola, como embudos llenos de dientes que buscan sombra, como rosas hechas de látigo y perfume, y aún, aún más, aún más. (Residencia..., III, "Las furias y las penas")

El acto sexual no es ya "oscuro" sino "colérico cauce", donde "el odio es un martillo". La calidad antitética de los rasgos con los cuales Neruda reviste a la amada respecto a aquellos que definen a la enemiga, no deben impedirnos reconocer la total coherencia de una concepción que ve al tú en función del yo. El tú amado no tenía existencia independiente del yo, su vivir se daba solamente en el recinto psíquico del poeta. El tú odiado tampoco tiene autonomía existencial: 
Ay cuántas veces eres la que el odio no nombra, y de qué modo hundido en las tinieblas, y bajo qué lluvia de estiércol machacado tu estatua en mi corazón devora el trébol.

Para que pudiera emerger del alma del poeta la mujer era amada en su silencio; ahora para que no invalide su carácter de enemiga, es necesario asesinarle la voz:

Es para que nunca, nunca hables, es para que nunca, nunca salga una golondrina del nido de la lengua y para que las ortigas destruyan tu garganta y un viento de buque áspero te habite.

En este poema de exterminios lo exterminado es todo lo vital. El tú enemigo rompe "a cuchilladas la madera"; esa "dulce materia" en la que el yo se había hundido en la fervorosa comunión de "Entrada en la madera". La madera, después de su propio cuerpo, es la sưstancia fundamental que el poeta descubre y quiere aprehender, "con mi razón apenas, con mis dedos", penetrar, hasta llegar a las mismas raíces. Esas raíces que siempre buscó y siempre buscará; esas raíces que por ser penetración en la tierra son doble símbolo del acto sexual y del origen último de todo lo vivo. En la madera tienen que estar encerrados también los buques de Temuco, las raices del poeta: Mater materita. Ante esta materia de sus origenes -aunque lleve en sí el color del mundo- se le revela no el mundo, sino su propio ser. En Neruda todo descubrimiento de lo exterior es, en última instancia, autodescubrimiento:

Es que soy yo ante tu color de mundo Soy yo ante tu ola de olores muriendo Soy yo con mis lamentos sin origen, sin alimentos, desvelado, solo, entrando oscurecidos corredores llegando a tu materia misteriosa.

Habiendo el yo huérfano reecontrado a la materia madre, se vuelve a establecer esa identificación constante en su poesía: madre-amada. Neruda 
canta entonces a esta amada elemental para luego, amante pasivo una vez más, rogarle que lo invada.
Poros, vetas, círculos de dulzura, peso, temperatura silenciosa
venid a mí, a mi sueño sin medida, caed en mi alcoba en que la noche cae
y cae sin cesar como agua rota, y a vuestra vida, a vuestra muerte asidme, a vuestros materiales sometidos.

Tambièn el apio llega a él con "aguas de raíces" para entrar en las "habitaciones funerales" del alma del poeta, y traer a su soledad el condensado prodigio de amor que es "la rosa de la tierra". El apio entra en él, como había querido que en él entrase la madera porque, aunque desde el título mismo, "Entrada en la madera", parece el poeta penetrar la materia, al final le pide que sea ella - nueva amante onírica- quien penetre en su "sueño sin medida", es decir, en su alma. Neruda es, una vez más, el amante receptor.

$\mathrm{Ha}$ aceptado ya el poeta, después de tantas negaciones, y a través de actos expresados en términos eróticos, primero el valor positivo de su cuerpo, después el de la materia fecunda que siente, y sentirá siempre, es la sustancia misma de sus propias raíces. Para terminar de aceptarse le falta ahora aceptar al hombre. Porque todo acto de Neruda, aunque aparentemente transitivo, es siempre reflejo: al descubtir la materia se descubre, al reconocer el valor del mundo se reconoce. El que se había "cansado de ser hombre", se da finalmente cuenta que los hombres no son lo extraño, sino que él es como ellos son. Neruda al aceptar a la huma. nidad lo que acepta es su propia humanidad: "yo de los hombres tengo la misma mano herida". Una vez más la revelación es sentida como acto de amor, consumado en sueños. Muy significativamente Neruda vuelve a ser surco receptor y ávido, donde cae, fértil, la semilla. La humanidad lo ha fecundado,

un día

palpitante de sueños

humanos, un salvaje

cereal ha llegado

a mi devoradora noche 
para que junte mis pasos de lobo

a los pasos del hombre. (Residencia..., III, "Reunión bajo

las nuevas banderas")

Ya grávido de gérmenes, elevará su voz en Canto general, canto a sus raices. El poeta no puede invocar en vano el nombre de América porque es y está

empapado en esperma de tu especie, amamantado en sangre de tu herencia. (VI, xviii)

América es, sobre todo, sentida como la madre, el gran "útero verde"; el vientre dentro del cual vive el poeta y de cuya tierra está hecho. La identificación vuelve a cumplirse, madre: tierra: yo. Al cantar a América, Neruda se canta en sus orígenes telúricos y en su propia sustancia vital. Pero de la ecuación poética falta uno de los términos prin. cipales, ¿por dónde la amada? Nos está esperando en Los versos del Capitán, y es toda ella "pequeña América"; posee así Neruda en las doradas latitudes de ese cuerpo tierra, patria, madre, amada, América:

Cuando miro la forma

de América en el mapa,

amor, a ti te veo:

las alturas del cobre en tu cabeza,

tus pechos, trigo y nieve,

tu cintura delgada,

veloces ríos que palpitan, dulces

colinas y praderas

y en el frío del sur tus pies terminan

su geografía de oro duplicado.

y al sabor de tu amor se agrega el barro

$y$ el beso de la tierra que me aguarda.

En Las uvas y el viento, Neruda identifica a Varsovia con la mujer querida, y canta su amor por Polonia, Hungría, Rusia, Italia y hasta por Inglaterra, en términos inconfundiblemente amorosos. Pero entre todas las tierras del mundo es su patria la madre, la novia ausente y deseada, su pequeña patria, querida "hasta las raíces". La identificación es nuevamente absoluta, pero su palabra, que había tenido la majestuosa sonoridad de un 
Magnificat para cantar a América, se hace al hablarle a Chile, intima, tierna, familiar. A su mujer le pide, ya lo hemos visto, que recuerde que él es un niño y no le abandone; a su amada Chile le ruega que lo acoja, como una madre "al niño lleno de llanto", en el "Himno y regreso" del "Canto general de Chile"; como la de su amada quiere abrazar la exigua cintura de su patria, y como la enamorada de Veinte poemas, aquella que parecía "que un beso le cerraba la boca", también Chile

todo era mío, todo

hacia mi en silencio levantaba

una boca de amor, llena de besos. (Canto general, $\mathrm{X}$, iii)

Desde Nietzsche creemos que todos los sistemas fillosóficos no son más que confesiones personales, porque uno solo puede expresarse a sí mismo: así Neruda, desde las alturas de Maóchu Picchu se enfrenta con las últimas preguntas del ser y del ser hombre. Como Zaratustra, subió Neruda a la montaña y encontró en sus soledades el águila y la serpiente, la muerte y. la resurrección. Nada más diferente que las concepciones filosóficas de Nietzsche y de Neruda, pero la pregunta de ambos desde las cimas pétreas, es la misma: 'ha de renacer el hombre, como un fénix, de sus propias cenizas? "QQué era el hombre?" ¿Dónde vivía lo indestructible, lo imperecedero, la vida?". ${ }^{6}$ El poeta se enfrenta con la esencia de la condición humana, lo temporal (III). Vivir es un ir muriéndose, pero Neruda no puede sino permanecer ajeno al anonimato de las muertes colectivas, porque éste es el mundo de 'lo otro', de lo que no puede amar,

No puedo amar en cada ser un árbol con su pequeño otoño a cuestas. (IV)

Como en el desamor le es imposible encontrar más que negaciones, el poeta, radicalmente solo, dice: "rodé muriendo de mi propia muerte". Esta, la suya, sí es muerte concreta, por eso puede ahora definirla (V). Habiendo confrontado la realidad última de la muerte y de su muerte, le es posible ascender a lo perdurable, aquello que ha vencido el tiempo: "la cuna del relámpago y del hombre" (VI). Machu Picchu, vértice donde se unen las dos vertientes trascendentales de la naturaleza y de la historia, "una permanencia de piedra y de palabra", "una vida de piedra después de tantas vidas" (VII). Permanencia y trascendencia han signi-

- "Alturas de Macchu Picchu", sección II. En adelante las referencias a este poema se indicarán con números romanos, correspondientes a las doce secciones que lo componen. 
ficado siempre para Neruda una sola cosa: amor; por eso a esta afirmación de lo perenne sigue su canto amoroso: "Sube conmigo, amor americano" (VIII). Como lo había hecho con la madera, esa otra cuna elemental, el poeta pide que este amor le penetre; entonces se le revela no sólo su propia temporalidad, sino la permanencia del granito histórico:

Ven a mi propio ser, al alba mía

hasta las soledades coronadas.

El reino muerto vive todavía.

Trasuntado de amor, quiere ahora el poeta resucitar al indio ancestral, como querrá un día resucitar a Varsovia, en acto de amor póstumo. Amor vidente que adivina en la nupcial belleza de la América antigua, el interminable dolor humano. Así como antes había sentido que a pesar de la belleza cósmica del cuerpo de la amada y a pesar de la posesión nupcial "la sed eterna sigue, y la fatiga sigue y el dolor infinito", también ahora siente que la fecundidad americana guarda secreto desolador:

también, también tus dedos

los que la rosa abstracta y la línea de frío, los

que el pecho sangriento del nuevo cereal trasladaron

hasta la tela de materia radiante, hasta las duras cavidades

también, también, América enterrada, guardaste en lo más bajo,

en el amargo intestino, como un águila, el hambre? (X)

En las altas soledades, donde Nietzsche se había identificado con el dominante Superhombre, Neruda se identifica con el esclavo sufriente porque, como lo había dicho ya al comenzar el Canto general, él es "incásico del légamo". Como con la madera, quiere primero aprehender digitalmente, $y$ después abarcar en sí la sustancia original de su ser histórico:

a través de la noche de piedra, déjame hundir la mano y deja que en sí palpite, como un ave mil años prisionera, el viejo corazón del olvidado! (XI)

Habiendo reconocido a su yo ancestral en el hermano antiguo y uniendo en él a la vez el pasado milenario y el eterno retorno futuro, que es en Neruda acto de resurrección por amor, puede ahora decirle:

Dadme el silencio, el agua, la esperanza, Dadme la lucha, el hierro, los volcanes. 
Apegadme los cuerpos como imanes.

Acudid a mis venas y a mi boca.

Hablad por mis palabras y mi sangre. (XII)

Neruda ha absorbido nuevamente el tú en el yo; y el largo peregrinaje en búsqueda de sus raíces llega a su cima: el poeta ha encontrado en Chile, en Macchu Picchu, en América, su propia sustancia, telúrica, histórica y social: "Estoy hecho de tus raíces".

Aun en este Canto general sigue Neruda tan circular como siempre; ya que en ése, el círculo de su yo, recibe, contiene y retiene todo lo can. tado. Su alma no se cierra ya "como una flor nocturna", pero tampoco deja entrar dentro de sí nada que sea, o que sienta, diferente de ella. Lo que esta alma ama es lo suyo, o lo que hace suyo por identificación o posesión. Neruda no puede amar sin poseer, como tampoco puede amar sin amarse. Porque él es "el nimbo metálico, la argolla/ encadenada a espacio, a nubes, a terrenos", en su círculo ávido, abarcándolo todo, el poeta se abraza. Neruda cierra cumplidamente el Canto general, cantándose explícitamente a sí mismo: "Yo soy", y uniendo así a la historia remota de sus orígenes la historia próxima de sus circunstancias.

\section{III.-PANEROTISMO}

En Las uvas y el viento reaparece el tú de la mujer amada, y desde ahora ella encerrará, sin abandonarla más, la naturaleza entera. El poeta, arquitecto de su propio mundo, construye el tú con los elementos del mundo entero:

Yo de mar y de tierra

te construí cantando. ("Te construí cantando")

La identificación entre amada y amante es sutil. La amada-hija está hecha de las mismas sustancia del amante-padre:

y que de mí, como del mar la espuma

tú naciste, pequeña diosa mía.

Sin embargo el padre-mar de esta Afrodita Anadiómene es, a la vez, surco de tierra donde cae la semilla fecundante. Más circular que nunca el poeta es ahora, padre y madre, surco sembrado y amante sembrador: 
Fuiste primero un germen acostado que esperaba

bajo la tierra oscura

el crecimiento de la primavera, y yo dormido entonces senti que me tocabas debajo de la tierra, porque ibas a nacer, y yo te había sembrado

dentro de mi existencia.

Es curioso que Neruda, quien suele identificar la amada con Afrodita, no haya sentido que, por lo contrario, la constante mítica detrás de su peregrinaje erótico es siempre la del más telúrico y misterioso de los mitos clásicos: Deméter-Perséfone, en el cual se unen muchos símbolos recurrentes en su poesía, que apunta así a un carácter esencialmente dionisíaco.

Ya desde el primer poema de Las versos del Capitán, en la mujer amada posee el poeta la tierra: "y me inclino a tu boca para besar la tierra". En las manos de ella reconoce él su propia materia original, y su peregrinaje de siempre se resume ahora en larga búsqueda de esas manos. Pero por primera vez esta mujer cósmica es un tú concreto y por serlo, el poeta no habla sino que le habla. Por fin hay un tú y un yo en diálogo; y porque para el diálogo hace falta la voz del tú, el mismo poeta que para su monólogo había deseado una amada muda, ahora le pide la risa y le reprocha el silencio:

A veces te hundes, caes

en tu agujero de silencio

$\ldots \ldots \ldots \ldots$

Amor mío, qué encuentras

en tu pozo cerrado?

$\mathrm{Mi}_{\mathrm{i}}$ vida, no hallarás

en el pozo en que caes

lo que yo guardo para ti en la altura:

un ramo de jazmines con rocío

un beso más profundo que tu abismo. ("El pozo")

Amante apasionado, es la suya a veces pasión agresiva y agresora, pero que no reduce el tú a la condición de víctima inerme, como en "Materia 
nupcial" de Residencia en la tierra, II. Ahora que hay comunión en todo, también la hay en la agresividad:

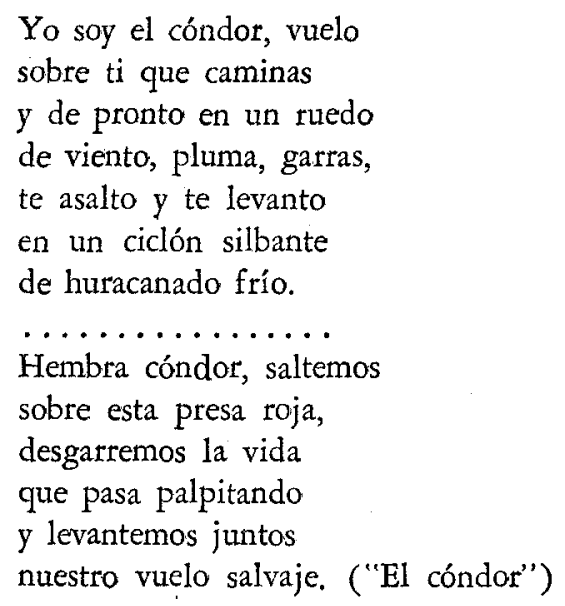

No es ya el tú mero instrumento, necesario para asegurar la sobrevivencia, que nunca hasta ahora, había el poeta expresado, más que en primera persona del singular. Ahora es tanto trascendencia como soledad de un nosotros,

Comenzamos de nuevo

terminamos de nuevo,

muerte y vida.

$Y$ aquí sobrevivimos

puros, con la pureza que nosotros creamos. ("Oda y germinaciones", III)

siempre estaremos tú y yo

solos sobre la tierra,

para comenzar la vida. ("Siempre")

Desde ese yo ávido de reconocer su propia sustancia en todo lo que ama, el poeta reconoce un tú que, aunque encierre en sí las raíces del yo, trasciende tanto al tú como al yo, porque hace posible el nosotros; y en el nosotros hace también posible otra forma de trascendencia: el yo en el tú, tanto como el tú en el yo,

Adiós, pero conmigo

serás, irás adentro 
de una gota de sangre que circule en mis venas

.............................

No he salido de ti cuando me alejo. ("La carta en el camino")

Neruda ha dejado las prisiones --castillo, casa, túnel, círculo- de un yo que hasta ahora no había conocido la profunda alegría del nosotros. Esta alegría acompañarál al poeta en el jubiloso mundo de sus Odas elementales, en el cual su deber es cantar para "propagar la alegria". Es la hora del nosotros, pero de un nosotros muy propio de Neruda; su yo, como proclama desde este amor universal, puede no tener importancia, pero ese yo sin importancia quiere abarcar en sí todas las vidas, para que todos vivan en la suya. Esto es en parte un darse pero, y sobre todo, un recibir, un necesitar de lo otro para ser verdaderamente él:

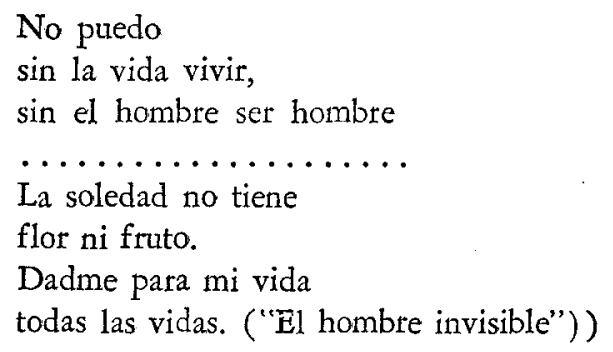

Luego de este rechazo a la soledad, el solitario de antaño decide poblarse no sólo de todas las vidas humanas, sino de la vida de todas las cosas, de la luna a la castaña; y todo lo hace suyo, como siempre, en posesión erótica. Su autoerotismo se ha expandido en panerotismo:

porque mi corazón guardaba toda germinación terrestre. ("Oda a la lluvia")

Desde su propia fecundidad canta el yo la fecundidad del mundo Como antes en la amada, ve a Afrodita Anadiómene en la cebolla, en el colibrí, "estructura de polen y semilla de sol", canta en el "germen total" que es el sol, al "gallo del universo". El mundo había sido en sus Residencias. .. un ir muriéndose, porque el yo lo veía desde sus diarias destrucciones; ahora es pujante fuerza vital, fecundidad inagotable, porque el poeta siente que en él es todo lo fecundo, y así en la "Oda a la fertilidad de la tierra", Neruda celebra su propia fertilidad: 


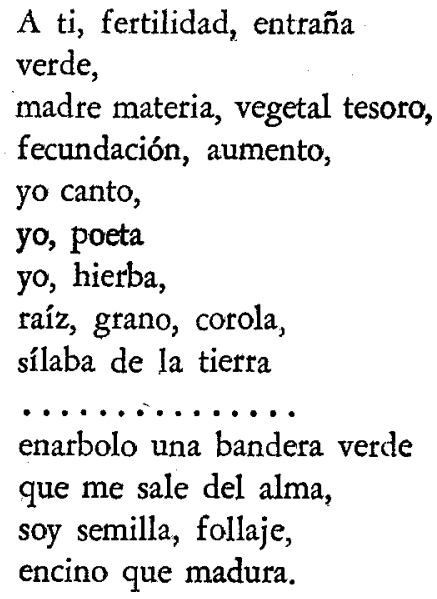

Tierra, semilla y flor, más que nunca es el poeta fecundador fecun. dado. Este erotismo suyo no es solamente pasividad natural; pues ya no le basta ser surco y semilla, desea ahora poseer la tierra y sembrar en ella sus "más profundos besos". Hasta le molesta la doncellez de las estrellas, "embarazadas" quiere contemplarlas y ser

polígamo

del espacio tálamo

nocturno. ("Oda a las estrellas")

Querría fecundar "la estatura helada" de la casta luna y convertir en "manantial de leche" sus virginales senos. Sea por posesión activa o por recepción pasiva, Neruda todo lo transmuta en sustancia erótica, porque su eros es de omnicomprensiva voracidad. Mejor que nadie sabe él que ha sido un viajero interior, un itinerante de sí mismo. El mundo exterior, en sus destrucciones y en sus nacimientos, ha sido siempre reflejo de este yo centrípeto que, titánico Narciso, transformó cada cosa en su espejo para, al contemplarla, contemplarse. $Y$ así, al recorrer el mundo se recorrió a sí mismo. Bien sabe él que se equivocó cuando

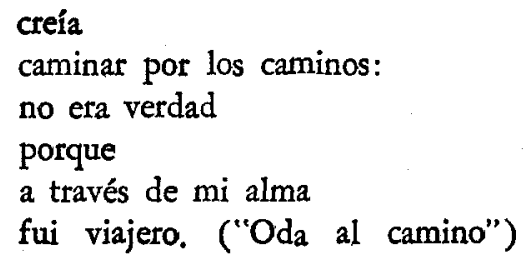


Bien sabe todo esto el poeta. Memorial de Isla Negrat es claro testimonio. El adolescente que se había definido como surco, fue siempre surco,

y fui fértil con todo

lo que caía en mí. ("La condición humana")

Así en "Deslumbra el dia", él recibe todo, todo lo acumula, todo cae en él. Pero para que sea verdaderamente suyo, ese mundo se hace pura subjetividad $y$, como revela en "La verdad", hasta puro sueño: "Amo lo que no tiene sino sueños/ Tengo un Jardín de flores que no existen". Desde el poema 15 de Veinte poemas, todas las cosas emergen de su alma, porque "todas las cosas están llenas" de su alma, también en $M e$. morial....,

La tierra surge, como si viviera en mí, cierro los ojos, luego existo. ("Territorios")

Cartesiano erótico, hizo del descubrimiento de su cuerpo, de sus raíces, de su sustancia vital, la sustancia de la amada, de la patria, de América, y del mundo. Su 'me amo, luego existo' se transformó en 'todo lo amo en mí, luego todo existe' tanto como en 'todo existe en mí, luego en todo me amo'. De ahí la imposibilidad de establecer una diferenciación absoluta entre su solitario autoerotismo juvenil y el exultante panerotismo de su madurez.

Si tomáramos como pauta para esta diferenciación su rechazo de la soledad tomaríamos por altruismo lo que fue erotismo. No porque en Neruda no haya momentos auténticamente altruistas; los hay, $\mathrm{y}$ poéticamente tal vez el más alto de ellos sea "El gran mantel" de Estravagario;" pero no es Agape, sino Eros la constante de este gran dionisíaco. Dionisíaco en el descenso al infierno de sus Residencias, en su avidez de raíces, tierra y frutos, dionisíaco en su deseo de luz y en su amor por "la verdad misteriosa", dionisíaco en su certidumbre de la muerte y en su afán de resurrección. Por eso es que aceptar su rechazo a la soledad sería desconocer algo muy profundo en el poeta: su apasionada necesidad de soledad. El Eros activo, el de las Odas elementales, puede en su afán de posesión negarla, porque lo que entonces importa es absorber, apoderarse, recibir, integrarse con los infinitos tús del mundo. Pero una vez cumplido el acto de amor, una vez integrado el tú al yo, queda el yo de Neruda

\footnotetext{
7 Bernardo Gicovate, "Dos notas sobre poesía y política", Ensayos sobre poesía bispánica (México, 1967), pp. 114-116.
} 
solo. Por eso en los últimos versos de esa larga contemplación de sí mismo que es Memorial de Isla Negra, el poeta nos dice su verdad de siempre: "lo importante es divisarse" y

ahora en este espacio descubietto

volemos a la pura soledad.

Alicia C. de Ferraresi

Stanford University 
